\title{
Effects of Pastoralists Communtity on Quality Education In Mandera County-Kenya.
}

\author{
Adan Maalim Hussein \\ Phd Student At Nehu-Shillong
}

\begin{abstract}
One of the most significant current discussions in the education arena is the provision of quality education. Education in Kenya is considered as basic tools for sighting poverty and ignorance, that is why it is considered as a basic right and basic need for every child to get education. The study focus on the following factors such as school-level factors with specific focus on; teacher qualification, socio-economic factors and community involvement to improve quality of education. Nomadic pastoralist is a subsistence system based on domesticated animal's production. There two forms of pastoralist nomadic and transhumance. Nomadic pastoralist do not have permanent settlements and often follow a seasonal migratory patterns whose living destinations are determined by needs of the herd animals for water and fodder; Pastoralists are seen as a minority community whose way of life and values are poorly understood and threatened by dominant social and political forces. The mobility of nomadic communities is likely to be affected by poor retention of teachers in rural areas. Owing to the generally low education levels in these communities, it is difficult to recruit enough teachers from the region. Therefore the areas are characterized by hash ecological zones that are prone to periodic droughts, low unreliable rainfall and a fragile environment that is subject to degradation. The lifestyles of the communities in the areas are also highly vulnerable in terms of poverty and insecurity. Due to unpredictable weather pattern that are characterized by inadequate rain full, nomadic pastoralist practices a mobile lifestyle in order to balance the water and grazing requirements of their livestock. There some hindering factors to girls' education and among these factors are the negative attitudes of the girls' parents and communities towards education such as boy-child preference, female genital cutting (FGC), early marriage, and excessive girl-child labour are the orders of the day. Given the prevalent high levels of poverty, provision of opportunities and material resources for girls' education was very limited. The main recommendations were community sensitization and mobilization, girls' own actions to pressure their parents to take them to school, provision of all-girls' schools staffed by female teachers, and grants and bursaries for poor bright girls.
\end{abstract}

Background of the study

\section{INTRODUCTION}

In the contemporary world, modern technology, formal education cultural integration, concern for quality life is gradually changing people's perspectives on their traditional beliefs and practices. However, this has not been so with the pastoralists (nomadic) communities who keep on moving with their livestock in search of water and pasture for their livestock.

There have been many attempts to establish education services to meet the leaning needs of the nomadic pastoralists. On the whole, they have failed for some, this because pastoralists are enable to develop beyond traditional economic practices and cling stubbornly to out dated cultural practices. Sometimes pastoralists are seen as a minority community whose way of life and values are poorly understood and threatened by dominant social and political forces. Nomadic lifestyle and form of livestock production has survived through centuries and globally. Today pastoral nomads are recognised as an efficient and cost-effective method of utilizing marginal lands.In the past, Kenya nomadic communities who occupy area designated as Arid and semi- Arid land (ASALS), have had strong and viable social system and community organization which enhanced self-reliance and survival capacity to meet their needs even at times of disaster such as drought. For centuries, milk and meat produced on the rangelands constituted the main diet of the nomadic communities, depending on the size the herd and pattern of droughts. However, since the market economy come in contact with the nomads, their diet substantially changed. Since then, pastoral nomads make regular trips to market in agricultural and urban settlement to obtain cereals. The integration of the Kenya nomads to the world economy is however constrained by their failure to fully embrace conventional education as reflected in low school Gross enrolment rates. Although the introductions of free primary Education (FPE) Programme in public schools by the government of Kenya in January 2003 raised the total primary school enrolment from 5.8million to 7.2million children, the case for nomadic areas has remained unimpressive. Most Children from (ASALS) areas have not fully benefited from the governments initiative as they live in hash socio-economic environment. 
In a document written to the ministry of Education by united nation state that every child in the nation must get basic education by 2015.The National commission for Education of the pastoralist and nomadic communities was set up with the mission to give special impetus in pastoralist and nomadic education to achieve the goals of Education for all with the hope of giving all members of these communities access to life education (Eshiwani 1993),

\section{REVIEW OF RELATED LITERATURE}

The main purpose of this literature review will be to understand what other writers have written about the effects of Kenya certificate of primary education (KCPE) performance in Mandera County. Many studies have been made by different Authors on school based factors, social - economic factors, community involvement and improvement strategies that should be used in the development and improvement of the student performance in primary education. These factors seem to be critical issues in the KCPE performance in Mandera County. This chapter therefore will help to appreciate what other researchers have contributed towards this field and assess what possibly need to be researched further. The chapter is divided into review of past studies /critical review and summary.

In the context of a renewal commitment to education for all (EFA) at DAKAR, this study examines the apparent failure of most attempts to provide education services to nomadic groups. Some see this failure as a pastoralists problem arguing that pastoralist are quite prepare for their children to be educated but they have tended to shun schooling because the provision in inappropriate in terms of relevance and location of schools. Others take the view that in as much as the education system aligned with modernity most formal education programmes are confronting for nomadic culture and what nomadic children need and want to know for their ways of life. (Okebukola, 1996)

There have been many attempts to establish education service to meet the learning needs of nomadic pastoralists; on the whole they have failed. For some this is because pastoralists are unable to develop beyond traditional economic practices and cling stubbornly to outdated cultural practices. For others pastoralists are minority community whose ways of life and values are poorly understood and threatened by dominant social and political factors. (Kakonge, 2000). Ezemoah and Pennell's (2000) also note that most programme for nomadic to a study by (UNICEF) on the challenge of implementing the convention on the rights of the children educational programmes for nomadic have failed primarily, because decision makers have sought to use education as a tool for transforming nomadic populations into sedentary ones. on recent research also underlines how projects of directed change are embedded into education for nomads and how such programmes antagonizes local pattern of learning and socialization. If education managers and planners saw schools as one way to change a conservative but troublesome people in order to ensure that nomads will one day cease to be nomads. Pastoralist had different perspectives where they see schools as both symbol of anew and alien culture. All inevitably pastoralist response of disinterest and passive resistance. In the long term, it made difficult for those who went to school to acquire the skill and knowledge needed to herd animals. Education was believed to alienate the young from prevailing social norms and values (Holland, 1996).

In Nigeria national primary school curriculum was adopted for nomadic schools in 1990 in order to be culturally relevant to the nomadic child while remaining on per- with non-nomadic schools and satisfying the national policy of integration and equity (Ezeomal 1993). Some countries in Africa like Mozambique Uganda and Eritrea have adopted in evening or flexible school timetable trying to minimize the dropout of children. In Chad there had been attempts to use milt-grade classes to bring about improvement in quality of basic education. However, implementation was ineffective and inefficient putting too much pressure on teachers with little training or support. It has been suggested that new approach adapted from Cohinsbran escheat Nuero Model, might be made successful especially with the nomadic groups (Harries 2000). This made emphasized the concept of self-learning and participation by learners. In Kenya Educational planning was dictated by the political and economic changes of 1963. Kenya Education commission or Ominde commission of 1964 laid the foundation for development of national education system with long range of providing universal education through primary level.

The national development plan period of 1970-1974 emphasized the expansion of education in all parts of the country with sizeable attention to the less developed arid and semi-arid areas. The Governments strategy to provide more educational opportunities through provision of free primary education to pastoralists and other disadvantaged groups did not have much impact on their development. Free primary education policy had numerous problems such as unable to cope with large influx of children especially in high populated regions. In areas where there are pastoralists the trend is not the same because of any cost fees and basic needs which children of pastoralists lack. The formal education system is unresponsive to the needs and living condition of children from marginal disadvantaged communities as well as to their changing context and to the potentials of existing community resources for educational process. Consequently, together with providing immediate responsive structures. (Keeves, J.P. and D. Kotte. 1996) 
According to save the children (2003), nothing can be gained by trying to get more children to school, unless those schools can be improved to the point of usefulness and essential mechanism for doing this is to involve children's parents, teachers, communities and Government official in process which will shift schooling in a more responsive direction.

\section{NOMADIC PASTORALIST LIFESTYLE}

Nomadic pastoralist is a subsistence system based on domesticated animal's production. There two forms of pastoralist nomadic and transhumance. While nomadic pastoralist do not create permanent settlements and often follow a seasonal migratory patterns whose living destinations are determined by needs of the herd animals for water and fodder; They letter follows a cyclical pattern of migration, therefore having seasonal migration between the same two location in which they have permanent abode. Pastoralist sometimes need interchangeable based upon maintained of herds of animals that mainly depend on natural vegetation for their foods. (Kelly, G. and C. Elliot. 1982)

This dependence along with migration to water, way from disease and in response to other pressure determine the seasonal and daily movement of pastoralists'(Awogbade,1991) while all members of pure nomadic pastoralist grow will be on the moves, there are some groups where a substantial fraction of group is settled in permanent habitat with perhaps only the younger men travelling with their livestock for periods of several months at a time and pastoralists require level of individual and social specialization. They can be very confident, articulate and entrepreurial have good negotiating and management's skills and have a strong sense of dignity and self respect. (Kinyanjui, K. 1987)

Although their lack of formal schooling is often seen as a problem (Ezeumal,1990),they are therefore far from being a mass of drafting unskilled under proletariat. Krath (2000) calls this the central paradox when discovering the issue of providing Education for nomadic pastoralists.

\section{SCHOOL BASED FACTORS}

School based factors increasly influence the difference in Kenya as more Kenyans are sending their children to educational centres, the pastrorists communities in Kenya who are preoccupied with search for pasture and water for livestock need conducive environment for learning. According to UNICEF study in 1990, the proximity and access is major determining factor to enrolment and retention of children. In arid and semiarid lands, distance between school and home and large education system are often incompatible with lifestyle of nomadic pastoralists. Other factors such as curriculum, instructional materials, qualified teachers, pedagogy, school atmosphere, education policy, cost of education and attitudes toward education, greatly affects academic performance.

Similarly, when the temporary water point dry-up teachers moves out to far locate trading centres (over $30 \mathrm{~km}$ away) where drinking water can be found. When the teacher moves out, pupils also join their parents in search for water and pasture. In most ASAL districts both boys and girls under enrol in formal schools, girls are the most disadvantaged. This leads to their failure to enrol in school and when they do the possibility of completing primary Education are very low. The main reasons for the under enrolment and early dropout of girls are both economic and social-cultural. Women in the ASAL region generally play the key role in the sustenance's of family. They ensure water and food is available for family while men's preoccupation is livestock herding. The girl child is therefore required to be at home to assist the mother in fulfilling the enormously tedious role given the level of poverty and hash climate. (MOE/FAWE Kenya Statistical Booklet, 2012).

\section{TEACHER'S QUALIFICATION.}

The mobility of nomadic communities means that they are likely to be particularly affected by poor retention of teachers in rural areas. Owing to the generally low education levels in these communities, it is difficult to recruit enough teachers from the region. There are even fewer nomadic women with the appropriate formal qualifications, which than leads to lack of appropriate examples from trained female teachers or role models for the girl child on issues of education. (Osman, A.O. 2002)Although the teachers service commission of Kenya decentralized the recruitment of teachers in (2001) with a major aim of ensuring retention of teachers in nomadic areas. The challenge of teacher, retention in nomadic districts still obtains. The key limitation of the teachers service commission (TSC) decentralization strategy was the provision for teaches who serves for five years to gain eligibility for transfer. Since nomadic areas still depend on teachers from external district, such teachers reportedly seek and find transfers immediately after five years bonding period. Even though the district Education Boards hire other teachers to replace the transferred teachers, such new teachers lack the necessary adaptive capabilities and Nomadic experience that is useful in nomadic schools. (Oyaya, E. 2000) 
Another factor that has late contributed to an acute shortage of teachers in nomadic district is the increase in the number of children in the schools due to free primary education. This policy has also lead to a proliferation of schools in some nomadic districts. Unfortunately the approved staff establishment for those districts have not been changed to reflect that reality. The Kenya Government has a policy in place of paying a hardship allowances to the teachers in nomadic areas. This, has however, not managed to solve the problem of understaffing in nomadic areas. Teachers in such areas find the current rates of hardship allowance extremely meagre compared to the risk and hardships associated with the nomadic district. (Truscot, K. 1994)

In terms of teacher training the aspect of not having any specialized curriculum for teachers earmarked to teach or already teaching in nomadic areas pose great capacity challenges to such teachers .Nigeria, for instance, has the Nomadic education centre at the university of Maiduguri (Nigeria) whose objectives is to undertake inservice training for serving teachers in nomadic schools. This is lacking in Kenya. (MacDonald, M. 2001)

\section{SOCIAL - ECONOMIC FACTORS}

The nomadic areas are characterized by hash ecological zones that are prone to periodic droughts, low unreliable rainfall and a fragile environment that is subject to degradation. The areas are also high vulnerable in terms of poverty and insecurity. Due to unpredictable weather pattern that are characterized by inadequate rain full, nomadic pastoralist practices a mobile lifestyle in order to balance the water and grazing requirements of their livestock. This mode of life puts most of them beyond the reach of conventional welfare services such as Education. (Kakonge, E.W. 2000)

Most of nomadic areas have marginal agricultural potential because of poor soils, low and unreliable rainfall that usually leads to prolong drought. This impacts negatively on the nutrition status of school children and thus interferes with the learning process. School absenteeism and even dropout that is related, lack of food is consequently high. Majority of the inhabitants, are nomadic pastoralist, denaturisation has been occurring because of communities losing their livestock during drought and banditry raids. This has led to such families clustering in camps or trading centres into anew strange way of life that merely expose them to more challenges and further vulnerability. (Kelly, G. and C. Elliot. 1982)

Most of the inhabitants of north Eastern province, which occupies a vast portion of Kenya ASAL region, subject to Islamic religion. Although Islam encourages the Education of both girls and boys, the rates of school enrolment and early school dropout are higher among girls than boys. This scenario is attributable to the fact that girls spend a great deal of their time and energy looking for water from the distance sources and also helping their mothers in laborious family chores. Those aside socio-cultural factors are also at the heart of gender imbalances in Education. For instances girls and women in the province are mainly viewed and valued for their reproductive capacity and domestic labour. (Okebukola P. 1996)

Socially, some arid and semi-arid lands (ASAL) Communities still hold the belief that an educated girl is morally depraved and may not easily play the role of a conformist wife. This makes there reluctant to educate the girl child thinking that the same would reduce her values. There also fear that at puberty, the girl's safety is not guaranteed as they may be seduced by either male teachers or by male pupils while travelling to and from distant schools. The latest statistical obtain from two KCPE school for the last five years, that is TAKABA DEB and Darwed primary school indicate that the number of girls is less than one third of the total candidate in Exams.

Analysis of Performance based on Subjects

\begin{tabular}{|l|c|c|c|}
\hline Subjects & $\begin{array}{c}\text { 2012 Subject mean } \\
\text { score }\end{array}$ & $\begin{array}{c}\text { 2013 subject mean } \\
\text { score }\end{array}$ & $\begin{array}{l}\text { 2014 Subject mean } \\
\text { score }\end{array}$ \\
\hline English & 39.16 & 46.65 & 43.62 \\
\hline Kiswahili & 40.28 & 39.42 & 35.8 \\
\hline Mathematics & 49.77 & 50.37 & 47.5 \\
\hline Science & 51.86 & 52.15 & 49.6 \\
\hline SSR & 49.89 & 50.37 & 47.7 \\
\hline
\end{tabular}

\section{Source - District Education Office KCPE analysis 2014}

The Kenya certificate of primary Examination KCPE is a very crucial examination in Kenya examination calendar. Not only does it measure the attainment of those who complete primary education cycle. It also the gauge of foundation on which all other Education and training is built. Unfortunately, the perception of KCPE exam amongst the ASAL communities is that, this Examination pays more attention to what pupils can remember than what they can do or how well they can reason. (Hyde, K. 1989)

The KCPE examination Questions are viewed as not being relevant to nomadic pastoralist. Judging from the above performances, it is doubtful that pupils from the above schools could actually get admission in national schools of any affirmative action for ASAL regions. Several reasons explain this dismal performance. 
Inadequate school facilities such as textbooks, classrooms, desk and toilets. Long distances to school erratic school attendances due to poverty and other social-cultural factors. (Okebukola P. 1996)

The current marginalization of arid and semi-arid lands (ASAL) areas in matters of formal education is deeply rooted in the historical colonization of Kenya by Britain in the $19^{\text {th }}$ and $20^{\text {th }}$ centuries. The colonial master differentiated regions in the ways they were incorporated in the colonial economy. The degree of incorporation depends on several factors among them, land value, response of the people to colonial subjugation and exploration, religious affiliation, and climatical condition. Unfortunately for arid and semi-arid lands (ASAL) areas, the disposition of its people, climate and land did note impress the colonial state apparatus and other agent of change. These areas therefore lay in the back yard or outer periphery of the colonial system. These districts and entry therein required special permits. These areas were therefore excluded from the process of modern education development as well as other socio-economic changes that were experienced in some other parts of the country. Due to this marginalization at independent in 1963, ASAL areas were the most educationally disadvantaged in the country. The low Education participation in nomadic areas began to be regarded as a serious political problem. The new government of Kenya faced the massive challenge of integrating the nomadic communities into the mainstream Kenyan society including education facilities (UNICEF Kenya 2008).

The first post independence Education commission which produced what is commonly known as the Ominde Report recommended a among others that main effort of the Government should be directed towards raising the level of enrolments of school going age children in nomadic areas. The commission further proposed that boarding and mobile school be established, although it qualified the sustainability of such initiatives and therefore recommended the evaluation of an economic plan which takes into account the creation of viable settled communities upon which the educational and other social services can be based. The Government thereafter in the early 1970 launched the remote areas primary boarding programme. The provision of boarding facilities in nomadic areas was meant to encourage more and more school attendance (UNICEF Kenya 2008).

However the amount of boarding fees and other cost that the pupil were required to bring like bedding, personal clothing were expensive and this hindered the smooth participation of the indigenous children of nomadic areas in the programme. An evaluation of the programme, at that time, revealed that most of the pupils enrolled in the boarding schools originated from the already education conscious districts. (Kelly, G. and C. Elliot. 1982)

\section{COMMUNITY INVOLVEMENT}

Many revitalization of primary school performance especially the KCPE performance in Arid and Semi-arid Lands (ASALs) are beginning of an entire community renewal. The long-term benefits of community involvement in this bid to improve the performance of primary education and especially the KCPE can include the creation of more jobs to the parents, improvement in community relations, community empowerment, and heightened economic status.

KCPE performance revitalization can be facilitated and enhanced by finding out what the children in the community needs, what will benefit the community, what has been tried in the past, and what could be done to improve past ideas. Community members, when given an opportunity to be informed and involved in the national exam performance improvement process and members may have special issues or concerns that can be incorporated into a problem solving at the outset. Successful community involvement is based upon information and dialogue. Only an informed community can be part of the decision- making process, which then will lead to a sustainable performance in KCPE in arid and semi arid districts. Community members who contribute to the KCPE performance improvement planning process will better understand the process and will be more likely to support a project they had input in.(Njau, W. and S. Wamahiu 1994.)

\section{STATEMENT OF THE PROBLEM}

Despite the government efforts to ensure access for education to pastoralists, children performance in Kenya certificates of primary education (KCPE) has remained a challenge due to their movement in search for water and pasture for their livestock.Primary schools in Mandera County are obtaining poor academic results. However, the trend seems to have worsened the last five years. Stakeholders blame head teachers for these disastrous results, alleging mismanagement and worried that something must be wrong somewhere.

Most of the inhabitants of North East Province, which occupies a vast portion of Kenyans ASAL region, subscribe to Islamic Religion. Although Islam encourages the education of both girls and boys, the rate of school enrolments and early school dropout are highly among girls than the boys. This scenario is attributable to the fact that girls spend a great deal of their time and energy, looking for water from distant sources and also helping their mothers in laborious family chores. That aside, social-cultural factors are also at the heart of gender imbalance in education.Many researches on academic performance in Kenyan primary schools have been carried out. However none of these studies have focused on the performance of primary schools in Takaba Division, despite of it being known nationally as poor performance in KCPE Examination. The poor 
performance has prompted the researcher to investigate and establish the actual causes of this situation, thereby filling this research gabs.

\section{PURPOSE OF THE STUDY}

The purpose of the study is to establish causes of poor performance and suggest remedies in KCPE performance. Education in Kenya is considered as basic tools for sighting poverty and ignorance, that is why it is basic right and basic need to every child to get it. Performance of child will therefore determine his future success and failures. For this reason the proposed study will seek to investigate the factors that affect the performance in KCPE in Takaba Division of mandera west. The study will focus on the in school factors which may affect performance such as the head-teacher.

\section{Research objective..}

The study will attempt to achieve the following specific objective.

1. To determine school base factors that influence KCPE performance in Takaba Division in Mandera west distinct.

2. To establish pupils socio-Economic background and their bearing in mind KCPE performance in Takaba Division.

3. To establish whether community involvement in school matter influence pupils KCPE performance in Takaba Division.

4. To suggest some strategies to improve KCPE performance within Takaba Division

\section{Significance of the study.}

The finding will enable educational policy makers to come up with policies to sensitize the nomadic society of Mandera County to encourage them to enrol more children in school.

\section{CONCEPTUAL FRAMEWORK}

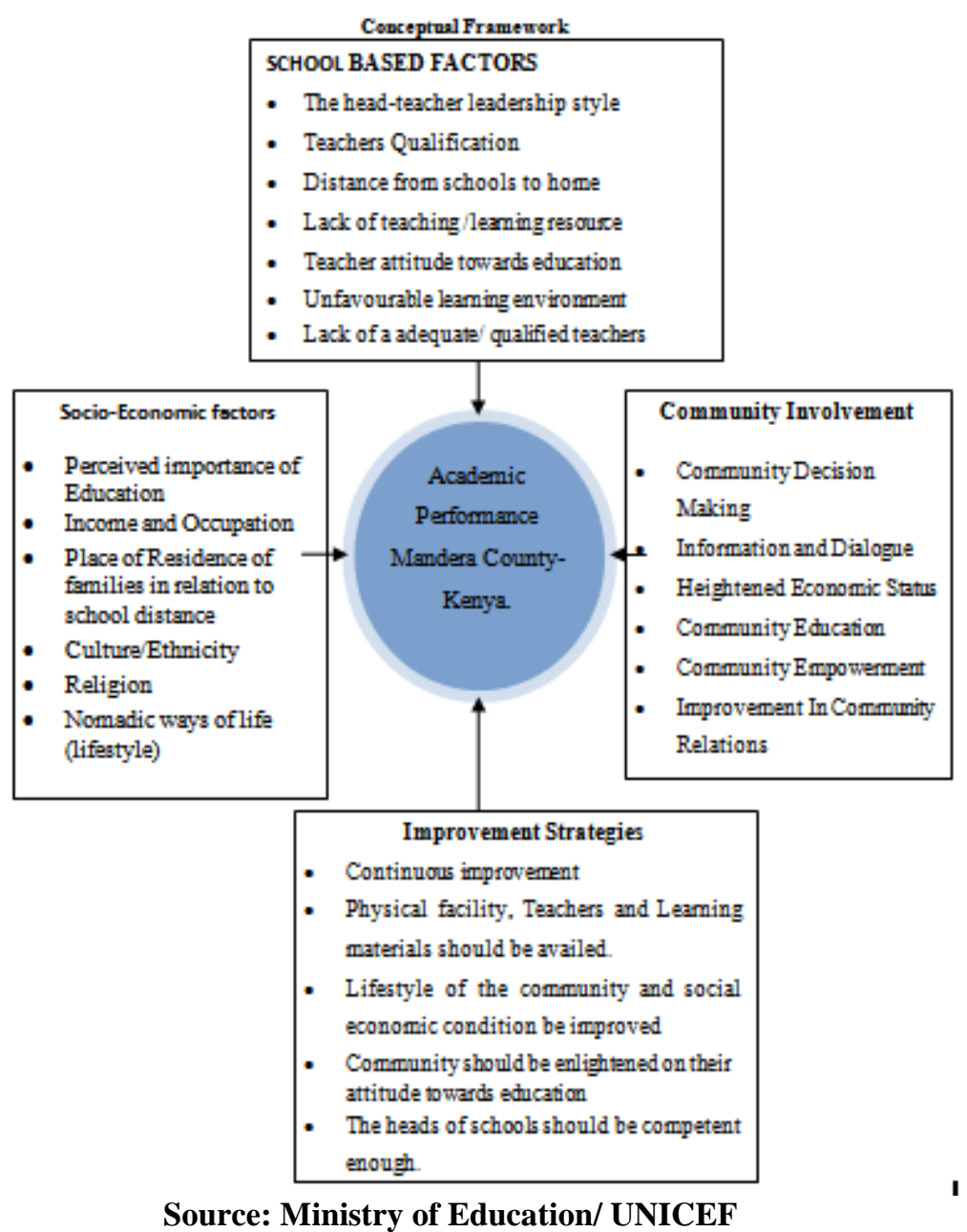

Source: Ministry of Education/ UNICEF 


\section{KCPE performance Improvement Strategies}

In spite of a national aim to achieve Education for All, basic education remains an elusive dream for many Kenyans, particularly girls in arid and semi-arid lands (ASAL). According to a study carried out by Forum for African Women Educationalists (FAWE), the findings show that at a theoretical level the three groups interviewed had positive perceptions of girls' education. However, they perceived the important factors hindering girls' education as outside themselves; among these factors are the negative attitudes of the girls' parents and communities, parameters related to patriarchy such as boy-child preference, female genital cutting (FGC), early marriage, and excessive girl-child labour. Given the prevalent high levels of poverty, provision of opportunities and material resources for girls' education was very limited. The main recommendations were community sensitization and mobilization, girls' own actions to pressure their parents to take them to school, provision of all-girls' schools staffed by female teachers, and grants and bursaries for poor bright girls. The government was seen to have an important role to play by enacting policies committing parents to educate all their children and making schools more girl-friendly. (Njau, W. and S. Wamahiu 1994)

A study of girls' education in Wajir and Mandera Districts of Kenya located in the North Eastern Province indicated that they are predominantly occupied by pastoral communities. There are diverse religious groups, the main ones being Muslims and Christians. The levels of access to education, especially that of girls, has been dismal in the two districts and performance in the national examinations, Kenya Certificate of Primary Education and Kenya Certificate of Secondary Education, has been poor compared with that in other districts. (MacDonald, M. 2001)

How to improve educational outcomes in North Eastern Province for both boys and girls has been a challenge to educationists and other stakeholders. Both the government and non-government organizations have indeed initiated many programmes, and several interventions have been put in place. However, academic results continue to be disappointing and remain below the national averages. There are few studies in the research literature on education in the two districts. The Task Force therefore considered the data from the perspectives of the NGOs based there, MOEST statistics and KNEC data. The NGOs considered the communities of North Eastern Province to be predominantly Islamic and pastoral. (Mulemwa, j 1997)

It is their view that the communities' perceptions of formal schooling are problematic, a majority supporting cultural practices such as FGC and early marriages, which have disappeared in most parts of the country. At the same time, strongly patriarchal traditional power and labour patterns continue to restrict women's and girls' access to resources and decision making roles. Poverty and high levels of illiteracy are thought to underlie the poor nutritional status and high mortality rates found in the community. Other that affecting girls' education includes: Very poor physical infrastructure coupled with a harsh environment. Inadequate physical facilities such as schools, equipment and supplies. Nomadism in search for water during dry spells. Limited community participation. Low levels of gender awareness/parents' negative attitudes that once girls are educated, they cannot make good wives or secure husbands. Therefore they prefer girls to learn only basic reading and writing. (Obura, A. 1991)Early marriages to older wealthy men who include chiefs and sheikhs. Thus common features of life in NEP are impoverishment and pervasive food stress, low levels of gender awareness, and prevalence of negative attitudes towards girls' education.

\section{Finding}

According to the findings carried out by the ministry of education (2000) the following strategies need be used to improve the performance of KCPE in Takaba Division and the whole performance of primary schools in Madera district: (Truscot, K. 1994)

The quality of the teachers needs to be addressed. Most primary school teachers were thought to have failed in school, particularly in mathematics and science subjects. In-service training of teachers was thought to be rare or nonexistent. Some teachers were thought not to have been in-serviced for 10-20 years, unlike in other areas where DEOs regularly organize in-service courses for teachers to motivate them and keep their methodology up to date.

The primary and secondary curriculum link was thought to be problematic. A comparison of KCPE and KCSE results shows a considerable decline in achievement levels in secondary schools, compared with what learners had achieved in primary schools.

Role models were also seen as important. The numbers of prominent women who have achieved are few. A useful role model was seen as that of a girl from the area who has achieved well in education against odds such as poverty and social-cultural and religious barriers. In other words, a self-made girl. (Osman, A.O. 2002) 


\section{SUMMARY.}

One of the interventions for nomadic communities in Kenya is the mobile school systems. This is an arrangement where a teacher is attached to nomadic family or a group of nomadic families moving together with their animals in search of pastures and water. The teacher with a nomadic back ground fits into the nomadic lifestyle and imparts some basic knowledge in a flexible manner. Both those who heard the animals and those who do not are taken care of.

\section{SCHOOL FEEDING PROGRAMME}

The school feeding programme was introduced TO the arid areas to give at least one meal to the children of the nomads. It is components were maize, beans and oil.

\section{LOW COST BOARDING SCHOOLS.}

As away to provide Education to children of nomadic communities, the government started the remote areas boarding programme. When the government fully funded the programme, the Boarding schools were filled to capacity. However the introduction of cost-sharing in 1988 lead to deteriation of the standards, particularly the diet and enrolment went down drastically. An evaluation of the programme (Krath 2001) showed that the Boarding schools were operating below capacity and not serving children of the pastoralists.In order to make boarding schools more attractive to nomadic pastoralists, the Government need to improve the boarding facilities and increase funding to the level it was cost-sharing. Nomadic Education is fully financed by the government and communities are not required to contribute financially. Variety of options for schooling is offered. Mobile-tented semi-permanent and fixed schooling. Children can easily move between systems and institutions, special recognition of traditional values and cultures are preserved. The requirement of teachertrainees from the nomadic regions on affirmative action basis and support them in meeting the cost of training. Female teacher-trainees will be specifically targeted for purpose of creating Educational role models in the communities. Teachers serving in nomadic areas will be provided with an-in-service training focused on nomadic conditions as multi-grade teaching. Better incentives will be considered to motivate the teachers deployed in nomadic region.

\section{REFERENCES}

[1] Abdistar, R. (1996). Gender disparities in Garissa District. PGDE project, Kenyatta University.

[2] Bennets (1973), Conflict and Decline of Pastoralists in the Horn of Africa, London. Macmillan press Limited.

[3] Coleman et al. (1966) The good Research Guide, $2^{\text {nd }}$ ed. England; Open University press

[4] Denscombe, (2003) Principles and practices of management. Sahitya Bhawan,.

[5] Eshiwani (2000). The good Research Guide, $2^{\text {nd }}$ ed. England; Open University press.

[6] Ezemoah and Pennell's (2000) A Study of Women's Access to Higher Education, with Reference to Mathematics and Science. Nairobi: Kenya Literature Bureau

[7] Ezeumal,(1990), the problems of educating Nomads in Nigeria, proceeding of the first Annual conference on education of nomads in Nigeria University of jos, Nigeria.

[8] FAWE/MOE/MTATT. (1995). Supporting the education of girls in science and mathematics Kenya. Research report. FAWE Regional Secretariat.

[9] Harries (2000) The Pastoralist Communities And Free Primary Education In Kenya. A preliminary survey by action Aid Kenya ministry of Education and Arid lands Resources management.

[10] Heyneman and Loxley(1982 and 1983) Case Study Research; Design And Methods. London; Sage Publication

[11] Holland, (1996). Tribal Schools of Iran Sedentarization through Education. Nomadic people publishers Tehran.

[12] Hyde, K. (1989). Improving Women's Education in sub-Saharan Africa. A review of the literature. Education and Employment Division, The World Bank.

[13] Kakonge, E.W. (2000). Gender Differences in Science Subjects in Secondary Schools in Kenya: An investigation of entries, attainment and teachers' perspectives. Unpublished $\mathrm{PhD}$ thesis, University of Leeds.

[14] Keeves p, et al (1999). Science Education in Nineteen Countries, An Empirical Study. New York: Wiley.

[15] Kelly, G. and C. Elliot. (1982). Women's Education in the Third World: Comparative Perspectives. State University of New York.

[16] Kinyanjui, K. (1987). Secondary School Education for Girls in Kenya: The need for a more sciencebased curriculum, to enhance women's greater access to development. Institute of Development Studies: University of Nairobi. 
[17] Kothari (2005) The Effect of primary-school Quality on academic achievement

[18] Krath (2001) Collaborate research in Education Administration.

[19] MacDonald, M. (2001). Schooling and the reproduction of class and gender relations. In L. Bartin, R. Meighan and S. Walker, eds. Schooling, Ideology and the Curriculum. Lewes: Falmer.

[20] MOE/FAWE Kenya Statistical Booklet (1999). FAWEK Secretariat at the Kenya Institute of Education.

[21] Mulemwa, j (1997) Status of Girls' Performance in Science, Mathematics and Technical Subjects. Female Education in Mathematics and Science in Africa (FEMSA) Project. Nairobi: Forum for African Women Educationalists (FAWE) Press.

[22] Njau, W. and S. Wamahiu (1994). School Dropout and Adolescent Pregnancy. Nairobi: Forum for African Women Educationalists.

[23] Obura, A. (1991). Portrayal of Girls and Women in Kenyan Textbooks. Nairobi: African Centre for Technology Studies (ACTS) Press.

[24] Okebukola P. (1996). Gender differences in perceptions In Research in Education: An Interdisciplinary International Research Journal, 55, Manchester University Press.

[25] Osman, A.O. (2002). Poor Performance in KCPE in North Eastern Province: ACase Study of Selected Schools in Wajir and Garissa Districts. PGDE Project, Kenyatta University.

[26] Oyaya, E. (2000). "Performance in KCSE examination in 1999". Daily Nation, 21 August 2000.

[27] Republic of Kenya (1964) Report of Education Commission, Ominde Report, Government printers, Nairobi.

[28] Rowley (1992), Education in Kenya since independent E .A E . P, Nairobi.

[29] Truscot, K. (1994). Gender and Education. Education Policy Unit, University of Witwatersrand, South Africa and UK: Oxford University Press.

[30] UNICEF. (2008) Country Programme of Cooperation between GOK and UNICEF: Master plan of operations.

[31] Yin (1994) Application of case study research. London. Sage Publication. 